\title{
Effects of the presence of a dominant follicle and exogenous oestradiol on the duration of the luteal phase of the bovine oestrous cycle
}

\author{
B. E. Salfen, J. R. Cresswell, Z. Z. Xu*, B. Bao ${ }^{\dagger}$ and H. A. Garverick ${ }^{\ddagger}$ \\ Department of Animal Sciences, University of Missouri, Columbia, MO 65211, USA
}

\begin{abstract}
The presence of a developing dominant follicle may be a factor in the control of the luteolytic cascade mechanism and the number of follicular waves during the bovine oestrous cycle. In this study, ovaries of all animals were examined once a day by transrectal ultrasonography. It was expected that heifers $(n=18)$ would have two follicular waves if the second wave occurred later than day 10 after oestrus (Expt 1 ) and that cows $(n=14)$ would have three waves if the second wave occurred on or before day 10 (Expt 2). The objective of Expt 1 was to determine if absence of a large follicle late in the luteal phase delays luteal regression in heifers that are expected to have two follicular waves. Nine heifers were injected i.v. with $10 \mathrm{ml}$ charcoal-treated bovine follicular fluid three times a day for 4 days, starting on the day after initiation of the second follicular wave, to delay growth of the second wave dominant follicle. Nine heifers were injected with $0.9 \% \mathrm{NaCl}$ as controls. The duration of the luteal phase (calculated as the number of days that serum progesterone was $>0.5 \mathrm{ng} \mathrm{ml}^{-1}$ ) was greater $(P<0.01)$ in the follicular fluid-treated group compared with the controls $(18.7$ versus 14.1 days). FSH and follicular growth were suppressed during the period of injection of follicular fluid ( $P<0.01$ and 0.03 , respectively). The objective of Expt 2 was to determine the effect of increased oestradiol on the duration of the luteal phase in cows that were expected to have three follicular waves. Seven cows were injected i.m. three times a day for 4 days with $1 \mathrm{ml}$ oestradiol $\left(100 \mu \mathrm{g} \mathrm{ml}^{-1}\right.$ in corn oil) and seven cows were similarly injected three times a day with $1 \mathrm{ml} 0.9 \% \mathrm{NaCl}$ (control) starting the day after cessation of growth of the second wave dominant follicle. Luteal phase duration was shorter in oestradiol-treated animals than in the controls (14.0 versus 19.0 days; $P<0.04)$. Serum oestradiol concentrations were higher in the oestradiol-treated group during the period of injection $(P<0.01)$. In summary, luteolysis was delayed when follicular growth was suppressed with follicular fluid (Expt 1). Exogenous oestradiol administration during the development of uterine oestradiol responsiveness initiated luteolysis earlier compared with control animals (Expt 2).
\end{abstract}

\section{Introduction}

Ovarian follicular growth in cattle normally occurs as cyclic waves of growth followed by either atresia or ovulation (Savio et al., 1988; Sirois and Fortune, 1988; Ginther et al., 1989). The growth pattern normally consists of recruitment of a number of follicles (cohort) of which one follicle is selected to continue growth and become the dominant follicle. During oestrous cycles with two follicular waves, initiation of the second wave takes place later (day 12 versus 9) and onset of luteal regression occurs earlier (day 16.5 versus 19) compared with oestrous cycles that have three waves of follicular development (Ginther et al., 1989; S. A.

*Present address: Livestock Improvement Corporation, Private Bag 3016, Hamilton, New Zealand.

†Present address: The Population Council, New York, NY 10021, USA

‡Correspondence and reprint requests.

Revised version received 5 August 1998
Hamilton, personal communication). The reason why some cattle have two waves of follicular development while others have three is unclear. It has been suggested that early onset of luteal regression in cows with two follicular waves prevents the emergence of the third wave (Sirois and Fortune, 1988; Ginther et al., 1989). This fails to explain why the early onset of luteal regression during oestrous cycles with two follicular waves is associated with a late initiation of the second follicular wave, which would also lead to delayed occurrence of a third wave. Steroid hormones, especially oestradiol and progesterone, are involved in the control of prostaglandin $\mathrm{F}_{2 \alpha}$ $\left(\mathrm{PGF}_{2 \alpha}\right)$ release from the uterus (McCracken et al., 1984). It is currently thought that as cows reach the late luteal phase, oestradiol receptors in the uterus are synthesized after progesterone receptor downregulation (Meyer $e t$ al., 1988). Oestradiol produced from the dominant follicle binds to its receptor and stimulates the synthesis of oxytocin receptors that, upon binding to oxytocin, cause release of $\mathrm{PGF}_{2 \alpha}$ from 
the uterus. Oestradiol production by the dominant follicle increases during growth of the follicle and decreases shortly after a plateau is reached (Padmanabhan et al., 1984; Xu et al., 1995). Thus, initiation of the second wave of follicles, and consequently the development of a dominant follicle, and its associated increased production of oestradiol, may influence the onset of luteal regression late in the oestrous cycle.

The objective of Expt 1 was to determine if a delay in the presence of the second wave dominant follicle (and oestradiol secretion) would culminate in a delay in luteolysis in heifers that were expected to have two waves of follicular development. Bovine follicular fluid that has been treated with charcoal to remove steroids decreases secretion of FSH by the anterior pituitary (Johnson and Smith, 1985; Quirk and Fortune, 1986; Moser et al., 1989a). Suppression of FSH by injection with follicular fluid delays development of the dominant follicle (Turzillo and Fortune, 1990) and, in turn, may delay the events preceding luteolysis. Bovine follicular fluid decreases secretion of FSH but not LH by the anterior pituitary in cattle (Johnson and Smith, 1985; Moser et al., 1989a).

The objective of Expt 2 was to determine if an extended period of oestradiol exposure during and after the second follicular wave would hasten the onset of luteolysis in animals expected to have three follicular waves. In cows expected to have three follicular waves, the supplemental oestradiol was administered at a time to extend the period during which the second wave dominant follicle would normally secrete oestradiol.

\section{Materials and Methods}

\section{Experiment 1}

Animals, treatments and blood collection. All procedures were approved by the Institutional Animal Care and Use Committee of the University of Missouri, Columbia. Eighteen dairy heifers with normal oestrous cycles were fed a diet to meet or exceed National Research Council (NRC) requirements and housed indoors in tether stalls. The heifers were expected to have two follicular waves and were assigned to two treatment groups (follicular fluid or saline (control) injection). Previous studies using the same herd of dairy heifers showed that approximately $90 \%$ of nulliparous animals had two waves of follicular growth during each oestrous cycle and $10 \%$ had three waves of follicular growth (S. A. Hamilton, personal communication). Two follicular waves were expected to occur if initiation of the second follicular wave occurred after day 10 . Oestrous cycles were synchronized with an intramuscular injection of $25 \mathrm{mg} \mathrm{PGF}_{2 \alpha}$ (Lutalyse; Upjohn, Kalamazoo, MI). Ovaries of heifers were examined by transrectal ultrasonography once a day starting from the day after PGF $_{2 \alpha}$ injection using an Aloka 210 realtime ultrasound instrument with a $7.5 \mathrm{MHz}$ probe. The diameter of follicles was measured to the nearest $0.5 \mathrm{~mm}$ using electronic callipers located on the ultrasound machine. Ovarian follicular populations and sizes were mapped and recorded during the scanning procedure. Blood samples were collected by tail vein venepuncture once a day from oestrus to the start of exogenous treatments, and three times a day during and after treatments. Blood samples were refrigerated at $5^{\circ} \mathrm{C}$ for $24 \mathrm{~h}$, centrifuged at $1500 \mathrm{~g}$ for $30 \mathrm{~min}$ and serum was collected and frozen at $-20^{\circ} \mathrm{C}$ until hormone analyses.

Follicular populations and maps were inspected once a day. Initiation of the second wave was defined as growth of at least two follicles that attained a diameter of at least $6 \mathrm{~mm}$. On the day after detection of the second follicular wave, nine heifers were injected i.v. with $10 \mathrm{ml}$ charcoal-treated bovine follicular fluid (Moser et al., 1989a) three times a day for 4 days at 07:00, 15:00 and 23:00 h. Control heifers were injected with saline. Concentrations of oestradiol and progesterone in the pooled follicular fluid preparations before and after charcoal treatment were $32.5,101.8$ and $0.03,1.0 \mathrm{ng} \mathrm{ml}^{-1}$, respectively. Data collection for individual heifers was terminated when an ovulation occurred as detected by ultrasound observation or when progesterone decreased below $0.5 \mathrm{ng} \mathrm{ml}^{-1}$.

\section{Experiment 2}

Animals, treatments and blood collection. Fourteen dairy animals with normal oestrous cycles that were expected to have three follicular waves on the basis of initiation of the second follicular wave were assigned to two treatment groups. Three follicular waves were predicted if the second wave occurred before day 10 . Initiation of the second wave was defined as growth of at least two follicles that attained a diameter of at least $6 \mathrm{~mm}$. All animals in Expt 2 were fed a diet to meet NRC requirements, administered $\mathrm{PGF}_{2 \alpha}$ and examined by ultrasonography as in Expt 1. The growth of follicles was monitored and plotted once a day. Seven animals were assigned to receive $1 \mathrm{ml}$ oestradiol $\left(100 \mu \mathrm{g} \mathrm{ml}^{-1}\right.$ in corn oil; Sigma, St Louis, MO) i.m. three times a day for 4 days starting from when the growth of the second wave dominant follicle reached a plateau (that is, it did not increase $>0.15 \mathrm{~cm}$ in diameter in $24 \mathrm{~h}$, as observed in two consecutive examinations). Seven animals were injected with saline as controls. The dose of oestradiol has been used for achieving follicular phase serum concentrations of oestradiol (Kieborz-Loos et al., 1994). Blood samples were collected once a day before (from oestrus) and after exogenous treatment and three times a day during the treatment period. Data collection for individual animals was terminated as in Expt 1.

\section{Hormone assays}

Serum concentrations of progesterone were measured by radioimmunoassay once a day using a commercially available kit (Diagnostic Products Corp., Los Angeles, CA) to determine luteal phase duration and mean serum progesterone concentration. This assay has been validated for bovine serum (Kirby et al., 1997). Intra- and interassay coefficients of variation (CV) for progesterone were 7.0 and $15.2 \%$, respectively, and the sensitivity of this assay is $0.05 \mathrm{ng}$ per tube.

Serum concentrations of oestradiol were measured by 
radioimmunoassay using an antibody and iodinated oestradiol from a commercially available source (ICN Biomedicals, Costa Mesa, CA), modified and validated according to Kirby et al. (1997). Intra- and interassay CV for oestradiol were 10.8 and $17.4 \%$, respectively, and the sensitivity of this assay is $0.5 \mathrm{pg} \mathrm{ml}^{-1}$.

Serum FSH was measured as described by Garverick et al. (1988) using NIAMDD-oFSH-RP-1 as the reference preparation. FSH was measured in all samples and concentrations were plotted throughout the cycle. Intra- and interassay CV for FSH were 6.3 and $9.8 \%$, respectively, and the sensitivity of the assay is $0.125 \mathrm{ng} \mathrm{ml}^{-1}$.

\section{Statistical analysis}

Hormone data were analysed using the general linear model (GLM) and least squares means procedure of Statistical Analysis System (SAS, 1988) with main effects of treatment, day of cycle, time of day (during treatment administration) and period. Endocrine data for both studies were divided into three periods. Periods 1, 2 and 3 consisted of data collected before, during and after treatment, respectively. Cow within treatment was used as the error term for endocrine analyses. All other data were analysed using the GLM procedure of SAS with main effect of treatment. The duration of the luteal phase was calculated from progesterone concentrations and was defined as the number of days above $0.5 \mathrm{ng} \mathrm{ml}^{-1}$. In addition, the day of luteolysis (from oestrus) was estimated to have occurred when serum progesterone decreased by $1.0 \mathrm{ng} \mathrm{ml}^{-1}$ compared with the mean of the three previous days and continued to decrease until it was below $0.5 \mathrm{ng} \mathrm{ml}^{-1}$. Follicular size and population data were summarized and the variables compared were: number of follicular waves per cycle; first, second (if present) and ovulatory wave follicle maximum size; number of follicles recruited per wave, size of dominant follicle at luteolysis; size of largest follicle at the beginning and end of the treatment period; growth rate of dominant follicle $\left(\mathrm{cm} \mathrm{day}^{-1}\right)$ during treatment period; day of the cycle that treatment was initiated; and whether luteolysis occurred while the treatment was in progress. Owing to the discrete nature of the last variable, proportional analysis was conducted for heifers in Expt 1 and the CATMOD procedure of SAS (SAS, 1988) was used for animals in Expt 2. CATMOD could not be used for Expt 1 data due to the absence of variability in treatment $2(0 / 9$ heifers underwent luteolysis during follicular fluid treatment administration). Follicular data were not divided into periods since data were single point measurements.

\section{Results}

\section{Experiment 1}

The day of the oestrous cycle on which treatment was started was not different between control and follicular fluid groups (day $13.7 \pm 0.4$ versus $12.8 \pm 0.5$, respectively; $P=0.17$ ). The duration of the luteal phase (least squares means \pm SEM $)$ was greater $(P<0.0001)$ for the heifers injected with follicular fluid ( $18.7 \pm 0.6$ days) than for the control animals (14.1 \pm 0.7 days). Luteolysis did not occur during treatment (period 2) in any of the animals in the follicular fluid-treated group $(n=9)$. Conversely, luteolysis commenced in five animals in the control group $(n=9)$ during period $2(P<0.01)$.

Mean progesterone concentration over all periods tended $(P=0.08)$ to be higher in animals injected with follicular fluid $\left(2.52 \pm 0.12 \mathrm{ng} \mathrm{ml}^{-1}\right)$ compared with control animals $(1.90 \pm$ $\left.0.18 \mathrm{ng} \mathrm{ml}^{-1}\right)$. There was a treatment $\times$ period interaction $(P=0.004$; Fig. 1a) and an effect of day of cycle $(P<0.0001)$. Within control heifers, mean progesterone concentration was lower in period 3 compared with period $1(P=0.03)$. Progesterone concentrations of animals injected with follicular fluid did not differ among periods. Progesterone concentrations between treatment groups were similar during periods 1 and 2. However, follicular fluid-treated animals had higher mean progesterone concentrations compared with control heifers $(2.75 \pm 0.31$ versus $1.27 \pm 0.44$ ng ml-1; $P=0.0003$ ) during period 3 (Fig. 1a).

There was an effect of day $(P=0.05)$ as well as a treatment $\times$ period interaction $(P=0.007)$ for mean serum concentrations of FSH (Fig. 1b). There was no difference among periods in control animals $\left(1.13 \pm 0.05,1.12 \pm 0.04\right.$ and $1.16 \pm 0.05 \mathrm{ng} \mathrm{ml}^{-1}$ for periods 1, 2 and 3, respectively). However, serum FSH concentrations were suppressed in follicular fluid-treated animals during period 2 compared with periods 1 and $3(0.87$ \pm 0.04 versus $1.04 \pm 0.05$ and $0.98 \pm 0.04 \mathrm{ng} \mathrm{ml}^{-1} ; P=0.0071$ and 0.0429 , respectively).

There was no difference in mean serum oestradiol concentrations between control and follicular fluid treatments $\left(6.05 \pm 0.3\right.$ versus $5.79 \pm 0.3 \mathrm{pg} \mathrm{ml}^{-1}$, respectively;

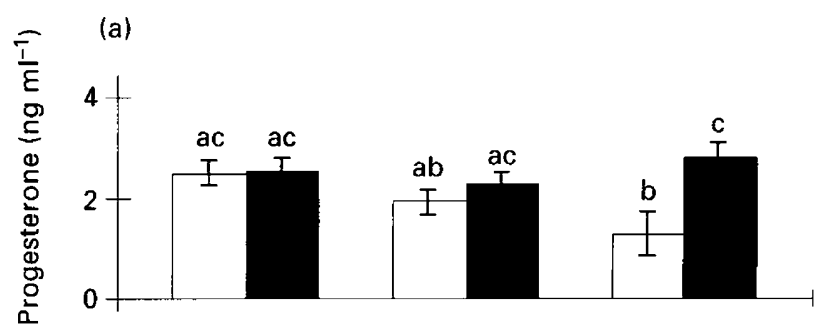

(b)

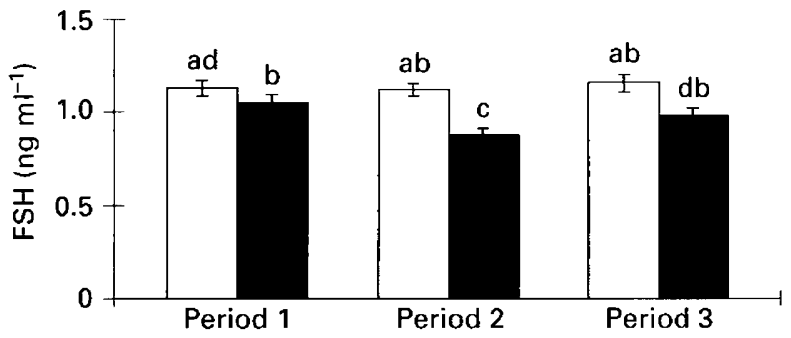

Fig. 1. Mean (a) progesterone and (b) FSH concentrations during different periods of the bovine oestrous cycle in animals injected with $(\square) 10 \mathrm{ml}$ charcoal-extracted follicular fluid or $(\square)$ saline three times a day for 4 days, commencing after detection of the second follicular wave (Expt 1). Periods 1, 2 and 3 correspond to data collected before, during and after treatment, respectively. Bars with different letters are significantly different $(P<0.05)$. 
$P=0.81)$. There was an effect of day of cycle $(P=0.0016)$, but there was no effect of period or treatment $\times$ period interaction.

Bovine follicular fluid suppressed follicular growth as expected. There was no difference in the size (mean \pm SEM) of the largest follicle at the start of treatment. However, the size of the largest follicle at the end of treatment was smaller in the group injected with follicular fluid $(P=0.0001)$ than in the control group (Table 1). Growth rate (measured as $\mathrm{cm}$ day $^{-1}$ increase in diameter) was higher in the controls than in treated animals.

The maximum size of the first wave dominant follicle was not different between control and follicular fluid-treated animals. The number of follicles recruited into the first wave cohort was similar between groups. The ovulatory wave parameters were also similar between groups. Dominant follicles on the ovaries of heifers receiving follicular fluid injections were smaller at luteolysis than those of control heifers (Table 1). Dominant follicles from the follicular fluidtreated animals were still in the growth phase at luteolysis, while the growth of dominant follicles in the control group was at or within 1 day of a plateau.

\section{Experiment 2}

The day of the oestrous cycle on which saline or oestradiol injections were initiated was similar between control and oestradiol-treated animals (day $14.6 \pm 0.8$ versus $15.0 \pm 1.1$; $P=0.76$ ). The duration of the luteal phase was shorter in oestradiol-treated animals compared with control animals $(14.0 \pm 0.4$ versus $18.9 \pm 2.2$ days; $P=0.046)$. Mean serum progesterone concentration was not different between control and oestradiol-treated animals during period 1 . However, during period 2, progesterone concentrations in control animals were higher $\left(3.45 \pm 0.26 \mathrm{ng} \mathrm{ml}^{-1}\right)$ than those of animals receiving oestradiol injections $\left(2.42 \pm 0.29 \mathrm{ng} \mathrm{ml}^{-1}\right.$; $P=0.002$; Fig. 2a). This difference was maintained into period $3(P=0.001)$, at least in part due to oestradiol-treated animals undergoing luteolysis during period 2 . There was a difference $(P<0.001)$ between control and treated animals in the occurrence of luteolysis during the treatment period. In the control group $(n=7)$, one animal underwent luteolysis during treatment. In the oestradiol-treated group $(n=7)$, six animals underwent luteolysis during administration of the hormone.

There were no differences between treatments in any parameters for FSH in Expt 2 (Fig. 2b). There were effects of day $(P=0.04)$ as well as a treatment $\times$ period interaction $(P<0.001)$ on serum oestradiol. There were no differences between treatments in serum oestradiol during period 1 . Concentrations of oestradiol were higher in the oestradioltreated group during period 2 (13.11 and $7.11 \mathrm{pg} \mathrm{ml}^{-1}$ for treated and control animals, respectively; $P<0.001$ ). Oestradiol concentrations in control animals were higher during period 3 compared with periods 1 and $2(10.42 \pm 0.84$, $5.72 \pm 0.93$ and $7.11 \pm 0.73 \mathrm{pg} \mathrm{ml}^{-1}$, respectively; $\left.P<0.005\right)$. Oestradiol concentrations were similar between treatments during period $3(P=0.4)$.

In the control group $(n=7)$, four animals had three follicular waves, two animals had two follicular waves and one had four follicular waves. The animal that had four follicular waves also had an oestrous cycle of 28 days; luteolysis occurred on day 24 of the cycle. In the oestradioltreated group ( $n=7)$, four animals had three follicular waves and three animals had two follicular waves (no difference between treatments; $P=0.4$ ). There were no differences in the other follicular parameters, including number of follicles per wave, maximum size of dominant follicles, size of largest follicle at luteolysis, size of largest follicle at the beginning and end of the treatment period, growth rate of follicle during treatment period, and day of luteolysis.

\section{Discussion}

The present study demonstrates that the presence of a dominant follicle or exogenous oestradiol administered at the appropriate time influences luteal regression. These findings support the hypothesis proposed by McCracken et al. (1984) that oestradiol binding to its receptor in the endometrium initiates a chain of events that culminates in

Table 1. Follicular parameters of cattle injected with follicular fluid or saline after initiation of the second follicular wave of the oestrous cycle

\begin{tabular}{lccc}
\hline Parameter & $\begin{array}{c}\text { Control } \\
\text { (mean } \pm \text { SEM) }\end{array}$ & $\begin{array}{c}\text { Follicular fluid } \\
\text { treatment } \\
\text { (mean } \pm \text { SEM) }\end{array}$ & $\begin{array}{c}\text { Significance } \\
\text { level }(P)\end{array}$ \\
\hline Size of follicle at start of treatment $(\mathrm{cm})$ & $0.72 \pm 0.03$ & $0.75 \pm 0.05$ & 0.58 \\
Size of follicle at end of treatment $(\mathrm{cm})$ & $1.20 \pm 0.05$ & $0.74 \pm 0.06$ & 0.001 \\
Growth rate of dominant follicle during treatment $\left(\mathrm{cm} \mathrm{day}^{-1}\right)$ & $0.18 \pm 0.07$ & $0.005 \pm 0.01$ & 0.02 \\
First wave follicle maximum size $(\mathrm{cm})$ & $1.26 \pm 0.05$ & $1.24 \pm 0.06$ & 0.77 \\
Number of follicles in first wave & $3.22 \pm 0.28$ & $3.55 \pm 0.56$ & 0.60 \\
Ovulatory wave follicle maximum size $(\mathrm{cm})$ & $1.26 \pm 0.04$ & $1.09 \pm 0.10$ & 0.12 \\
Number of follicles in ovulatory wave & $4.55 \pm 0.44$ & $4.11 \pm 0.61$ & 0.56 \\
Follicle size at luteolysis $(\mathrm{cm})$ & $1.20 \pm 0.04$ & $0.79 \pm 0.07$ & 0.0001 \\
\hline
\end{tabular}

Treatments consisted of injections of saline (control) or follicular fluid ( $10 \mathrm{ml}$ i.m.) three times a day for 4 days.

Follicles of at least $6 \mathrm{~mm}$ diameter were counted in the follicular waves. 
(a)

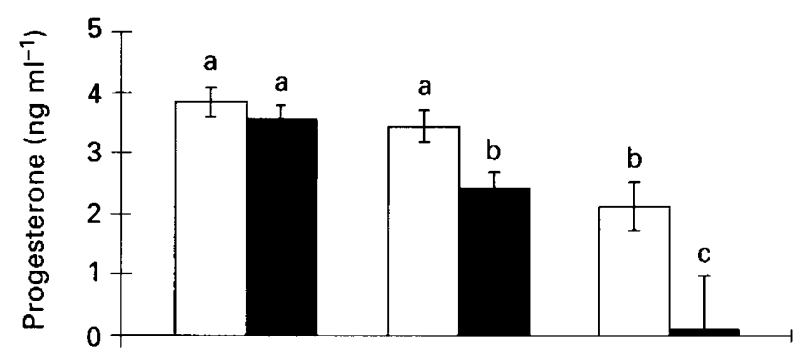

(b)

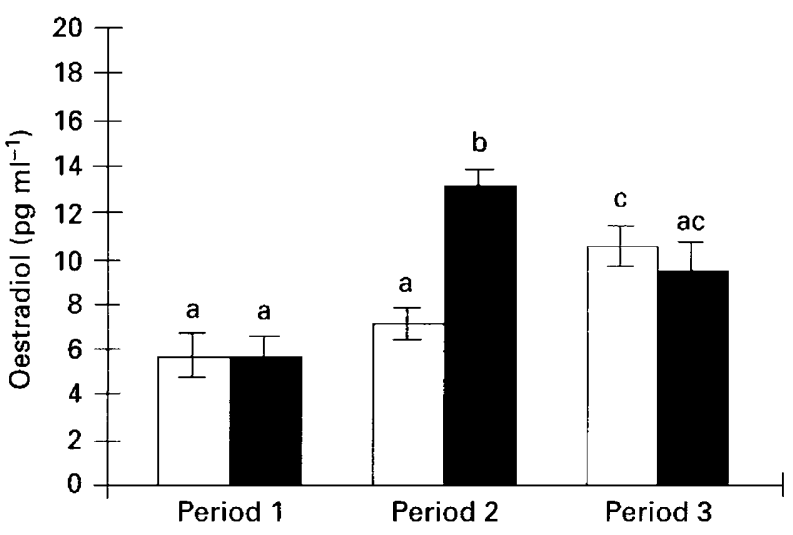

Fig. 2. Mean (a) progesterone and (b) oestradiol concentrations during different periods of the bovine oestrous cycle in animals injected with $(\boldsymbol{\square}) 100 \mu \mathrm{g}$ oestradiol or $(\square)$ saline three times a day for 4 days commencing after the second follicular wave reached a plateau (Expt 2). Periods 1, 2 and 3 correspond to data collected before, during and after treatment, respectively. Bars with different letters are significantly different $(P<0.05)$.

luteolysis. Key steps in this hypothesized pathway are the activation and synthesis of oxytocin receptors induced by oestradiol binding to its own receptor to induce the eventual release of $\mathrm{PGF}_{2 \alpha}$ after oxytocin-receptor binding. Another key point is the modulatory role of progesterone on oestradiol receptor binding and oxytocin receptor upregulation. Progesterone inhibits the ability of oestradiol to increase endometrial concentrations of receptors for oxytocin in rabbits (Nissenson et al., 1978) and sheep (Koligian and Stormshak, 1977). However, Vallet et al. (1990) reported an increase in the concentration of receptors for oxytocin in ovariectomized ewes treated with progesterone for 12 days. Downregulation of progesterone receptors in the uterine endometrium is hypothesized to occur after continuous infusion of progesterone in ewes with autotransplanted uteri (McCracken et al., 1984). Downregulation of progesterone receptors effectively enables the upregulation of oxytocin receptors by oestradiol. The period of progesterone exposure that is required before $\mathrm{PGF}_{2 \alpha}$ release can occur is approximately 10 days in ewes (Bray and Hecker, 1976; Vallet and Lamming, 1991; Beard and Lamming, 1994) and 12 days in cows (Lamming and Mann, 1995).

In Expt 1, the duration of the luteal phase was greater in follicular fluid-treated heifers compared with controls.
Furthermore, the day of the oestrous cycle on which luteolysis occurred also differed between treatments. Luteolysis did not occur in any of the animals during the period of follicular fluid injections. However, luteolysis commenced in five of the control animals during the treatment period. Serum oestradiol concentrations did not differ in follicular fluid-treated animals compared with controls. The finding that marked suppression of follicular growth is not closely associated with suppression of serum oestradiol is not uncommon on the basis of previous studies (Moser et al., 1989b) and is at least in part due to the variability of oestradiol in samples.

In Expt 2, oestradiol was administered during the plateau phase of the second follicular wave in animals that were expected to have three waves. The higher concentration or the increased duration of oestradiol exposure may have induced luteal regression in animals in the oestradiol-treated group. Secretion of oestradiol by dominant follicles of the second follicular wave in the control animals probably decreased before the loss of progesterone dominance in this group. Since oestradiol treatment was given on or around day 13 through to day 16 of the oestrous cycle, significant endogenous progesterone was present for at least 10 days before the end of oestradiol treatment. If progesterone receptors were downregulated sufficiently before the end of oestradiol treatment, oxytocin and $\mathrm{PGF}_{2 \alpha}$ synthesis and release may have been stimulated. Similarly, in animals with two waves of follicular growth compared with those with three waves, the timing of progesterone receptor downregulation and prostaglandin $\mathrm{H}$ synthase activity may determine whether the oestradiol produced by the second wave dominant follicle is effective in initiating the luteolytic cascade (Lamming and Mann, 1995). The effects of oestradiol on follicles are likely to be mediated indirectly via the hypothalamus and pituitary. Oestradiol receptor $\beta$ has been found in bovine follicles (Rosenfeld et al., 1998). However, the dose of oestradiol administered in the current study would probably not affect follicular concentrations of oestradiol, which are normally much greater in follicles than in the circulation. The indirect effects of oestradiol are likely to be through a reduction in FSH secretion. Oestradiol decreases plasma FSH concentrations in ovariectomized ewes (Goodman and Karsch, 1980; Rawlings et al., 1984; Tamanini et al., 1986) and cattle (Ireland and Roche, 1982; Butler et al., 1983; Schoenemann et al., 1985; Price and Webb, 1988). Furthermore, Price and Webb (1988) reported that physiological concentrations of oestradiol alter the distribution of follicle sizes. However, in the same study, there was no alteration in the number of antral follicles after implantation of oestradiol implants to achieve physiological concentrations of oestradiol (Price and Webb, 1988).

A marked response was seen in follicular dynamics in Expt 1. The start of the second follicular wave that was delayed by follicular fluid treatment was not considered to be a wave since dominance was not achieved by any follicle in the cohort. Administration of follicular fluid did not alter the number of follicular waves per cycle. However, control heifers had an average of 2.1 follicular waves per cycle, which indicates that predicting the number of follicular waves on the basis of parity of the animal and the time of 
emergence of the second follicular wave is an accurate method in this group of animals. Follicular data (number of follicles per wave and maximum size) were not different between groups before treatment. The growth rate of follicles was higher during period 2 in the control group compared with the follicular fluid-treated animals. The growth rate of the second wave dominant follicle was $0.18 \mathrm{~cm} \mathrm{day}^{-1}$ in control animals during period 2 compared with $0.005 \mathrm{~cm}$ day $^{-1}$ in the follicular fluid-treated group. This is similar to the findings of Turzillo and Fortune (1991, 1993). Charcoaltreated bovine follicular fluid was used as a tool to suppress FSH and the growth of second wave follicles selectively. In the present study, follicular fluid suppressed serum FSH during the treatment period. The inhibitory effects of follicular fluid on follicular growth have been studied extensively (McNeilly 1984, 1985; Johnson and Smith, 1985; Johnson et al., 1985; Quirk and Fortune, 1986; Moser et al., $1989 \mathrm{a}, \mathrm{b})$.

Oestradiol administration did not influence follicular dynamics (Expt 2). As expected, the growth rate of follicles declined slightly during the treatment period in both control and oestradiol-treated groups. Oestradiol treatment was initiated so that serum oestradiol concentrations remained high for a longer period compared with control animals. In addition, serum oestradiol concentrations in oestradioltreated animals during period 2 were higher than those of control animals in periods 2 or 3 . The serum oestradiol concentrations remained within physiological limits $8 \mathrm{~h}$ after injection.

In summary, the presence of a growing dominant follicle or injection of exogenous oestradiol during the late luteal phase in cattle is associated with luteolysis. The primary luteolytic role of oestradiol in luteolysis has been discussed extensively. However, the exact role of oestradiol remains unclear The primary effect of oestradiol on luteolysis is thought to be associated with the release of $\mathrm{PGF}_{2 \alpha}$ and oxytocin from the uterus and corpus luteum, respectively. In animals expected to have two follicular waves, emergence of the second follicular wave occurs later (day 12) and the dominant follicle is in a growing phase when the uterus becomes responsive to oestradiol. Another possible explanation is that the serum oestradiol concentration achieved by the second wave dominant follicle, as well as the timing of oestradiol production, may be insufficient to trigger the luteolytic cascade.

Contribution from the Missouri Agricultural Experiment Station Journal Series Number 12,661 and Regional Research Project, NC113, Methods for Improvement of Fertility in Cows Postpartum.

\section{References}

Beard AP and Lamming GE (1994) Oestradiol concentration and the development of the oxytocin receptor and oxytocin induced prostaglandin $F_{2 x}$ release in ewes Journal of Reproduction and Fertility $100469-475$

Bray AR and Hecker JF (1976) Role of progesterone in regulating the length of the oestrous cycle in the sheep Journal of Reproduction and Fertility 46 522-523

Butler WR, Katz LS, Arriola J, Milvae RA and Foote RH (1983) On the negative feedback regulation of gonadotropins in castrate and intact cattle with comparison of two FSH radioimmunoassays Journal of Animal Science $56919-929$
Garverick HA, Parfet JR, Lee CN, Copelin JP, Youngquist RS and Smith MF (1988) Relationship of pre- and postovulatory gonadotropin concentrations to subnormal luteal function in postpartum beef cattle journal of Animal Science 66 104-111

Ginther OJ, Knopf L and Kastelic JP (1989) Temporal associations among ovarian events in cattle during oestrous cycles with two and three follicular waves Journal of Reproduction and Fertility 87 223-230

Goodman RL and Karsch FJ (1980) Pulsatile secretion of luteinizing hormone: differential suppression by ovarian steroids Journal of Endocrinology 107 $1286-1290$

Ireland JJ and Roche JF (1982) Effect of progesterone on basal LH and episodic LH and FSH secretion in heifers Journal of Reproduction and Fertility 64 295-302

Johnson SK and Smith MF (1985) Effects of charcoal-extracted bovine follicular fluid on gonadotropin concentrations, the onset of estrus and luteal function in heifers Journal of Animal Science 61 203-209

Johnson SK, Smith MF and Elmore RG (1985) Effect of unilateral ovariectomy and injection of bovine follicular fluid on gonadotropin secretion and compensatory ovarian hypertrophy in prepubertal heifers Journal of Animal Science 60 1055-1060

Kieborz-Loos KR, Smith MF, Keisler DH, Youngquist RS, Hamilton SA, Salfen BE and Garverick HA (1994) Oxytocin-induced release of prostaglandin $\mathrm{F}_{2 \alpha}\left(\mathrm{PGF}_{\alpha}\right)$ in postpartum beef cows: effects of progesterone $(\mathrm{P})$ and estradiol-17ß (E) treatment Journal of Animal Science 72 Supplement 2 Abstract 144

Kirby CJ, Smith MF, Keisler DH and Lucy MC (1997) Follicular function in lactating dairy cows treated with sustained-release bovine somatotropin Journal of Dairy Science 80 273-285

Koligian KB and Stormshak F (1977) Progesterone inhibition of estrogen receptor replenishment in ovine endometrium Biology of Reproduction 17 412-416

Lamming GE and Mann GE (1995) Control of endometrial oxytocin receptors and prostaglandin $\mathrm{F}_{2 \alpha}$ production in cows by progesterone and oestradiol Journal of Reproduction and Fertility 103 69-73

McCracken JA, Schramm W and Okulicz WC (1984) Hormone receptor control of pulsatile secretion of $\mathrm{PGF}_{2 \alpha}$ from the ovine uterus during luteolysis and its abrogation in early pregnancy Animal Reproduction Science 731-55

McNeilly AS (1984) Changes in FSH and the pulsatile secretion of LH during the delay in oestrus induced by treatment of ewes with bovine follicular fluid Journal of Reproduction and Fertility 72 165-172

McNeilly AS (1985) Effect of changes in FSH induced by bovine follicular fluid and FSH infusion in the preovulatory phase on subsequent ovulation rate and corpus luteum function in the ewe Journal of Reproduction and Fertility 74 661-668

Meyex HDD, Mittermeier Th and Shams D (1988) Dynamics of oxytocin estrogen and progestin receptors in the bovine endometrium during the estrous cycle Acta Endocrinologica (Copenhagen) 118 96-104

Moser MT, Garverick HA, Smith MF and Youngquist RS (1989a) Follicular growth and endocrine patterns of prepubertal heifers administered bovine follicular fluid and (or) follicle stimulating hormone Animal Reproduction Science 18 227-242

Moser MT, Garverick HA, Smith MF and Youngquist RS (1989b) Effect of bovine follicular fluid and follicle-stimulating hormone on follicular growth in unilaterally ovariectomized prepubertal heifers Journal of Dairy Science 72 2170-2178

Nissenson R, Flouret G and Hechter $\mathbf{O}$ (1978) Opposing effects of estradiol and progesterone on oxytocin receptors in rabbit uterus Proceedings National Academy of Science 75 2044-2048

Padmanabhan V, Convey FM, Roche JF and Ireland JJ (1984) Changes in inhibin-like bioactivity in ovulatory and atretic follicles and utero-ovarian venous blood after prostaglandin-induced luteolysis in heifers Endocrinology 115 1332-1340

Price CA and Webb R (1988) Steroid control of gonadotropin secretion and ovarian function in heifers Endocrinology 122 2222-2231

Quirk SM and Fortune JE (1986) Plasma concentrations of gonadotropins, preovulatory follicular development and luteal function associated with bovine follicular fluid-induced delay of oestrus in heifers journal of Reproduction and Fertility 76 609-621

Rawlings NC, Jeffcoate IA and Rieger DL (1984) The influence of estradiol$17 \beta$ and progesterone on peripheral serum concentrations of luteinizing hormone and follicle stimulating hormone in the ovariectomized ewe Theriogenology 22 473-478

Rosenfeld CS, Yuan X, Manikkam M, Calder MD, Garverick HA and Lubahn DL (1998) Sequencing, cloning, and localization of bovine estrogen 
receptor-beta (ER $\beta)$ in the reproductive tract of the cow Biology of Reproduction 58 Supplement 1 Abstract 120 108-109

SAS (1988) SAS User's Guide: Statistics SAS Institute Inc., Cary, NC

Savio JD, Keenan L, Boland MP and Roche JF (1988) Pattern of growth of dominant follicles during the oestrous cycle of heifers Journal of Reproduction and Fertility 80 663-671

Schoenemann HM, Humphrey WD, Crowder ME, Nett TM and Reeves JJ (1985) Pituitary luteinizing hormone-releasing hormone receptors in ovariectomized cows after challenge with ovarian steroids Biology of Reproduction 32 574-583

Sirois J and Fortune JE (1988) Ovarian follicular dynamics during the estrous cycle in heifers monitored by real-time ultrasonography Biology of Reproduction 39 308-317

Tamanini C, Crowder ME and Nett TM (1986) Effects of oestradiol and progesterone on pulsatile secretion of luteinizing hormone in ovariectomized ewes Acta Endocrinologica (Copenhagen) 111 172-178

Turzillo AM and Fortune JE (1990) Suppression of the secondary FSH surge with bovine follicular fluid is associated with delayed ovarian follicular development in heifers Journal of Reproduction and Fertility 89 643-653
Turzillo AM and Fortune JE (1991) Fate of dominant ovarian follicles in heifers following suppression of plasma FSH Journal of Animal Science 69 Supplement 1 Abstract 602

Turzillo AM and Fortune JE (1993) Effects of suppressing plasma FSH on ovarian follicular dominance in cattle Journal of Reproduction and Fertility 98 113-119

Vallet JL and Lamming GE (1991) Ovine conceptus secretory proteins and bovine recombinant interferon $\alpha_{1}-1$ decrease endometrial oxytocin receptor concentrations in cyclic and progesterone-treated ovariectomised ewes Journal of Endocrinology 131 475-482

Vallet JL, Lamming GE and Batten M (1990) Control of endometrial oxytocin receptor and uterine response to oxytocin by progesterone and oestradiol in the ewe Journal of Reproduction and Fertility 90 625-634

Xu ZZ, Garverick HA, Smith GW, Smith MF, Hamilton SA and Youngquist RS (1995) Expression of messenger ribonucleic acid encoding cytochrome P450 side-chain cleavage, cytochrome P450 17 $\alpha$-hydroxylase, and cytochrome P450 aromatase in bovine follicles during the first follicular wave Endocrinology 136 981-989 